\title{
Cooling rates in high pressure granulite from Southern Brasília Orogen (SE-Brazil)
}

\author{
R.A. Fumes 1*, G.L. LUVIZOTTO 1, C. M. VALERIANO2
} AND R. MORAES3

1Department of Geology, São Paulo State University, 13506900, Rio Claro, Brazil. (*regiane.fumes@unesp.br)

${ }_{2}$ Faculdade de Geologia, Rio de Janeiro State University, 20550-900, Rio de Janeiro, Brazil

3Geoscience Institute, University of São Paulo, 05508-080, São Paulo, Brazil

A combination of U-Th-PbT monazite EPMA dating and LA-ICP-MS rutile dating is used to assess the cooling rates of high-pressure granulite from the Passos Nappe (SE - Brazil). These rocks have a pelitic protolith and record a peak assemblage of garnet + kyanite + rutile $+\mathrm{K}$-feldspar + melt formed at $860{ }^{\circ} \mathrm{C}$ and $1.8 \mathrm{GPa}$. Retrograde conditions of 800 ${ }^{\circ} \mathrm{C}$ and $1.0 \mathrm{GPa}$ are marked by grossular content, anorthite composition and biotite crystallization. Metamorphic peak conditions occurred $c a$. $635 \mathrm{Ma}$, based on monazite dating, whereas rutile ages of $c a .590$ Ma record the late retrograde stage (at $c a .600{ }^{\circ} \mathrm{C}$ ), associated with late chlorite replacing biotite. Muscovite K-Ar ages in the Passos Nappe of $c a$. 570$580 \mathrm{Ma}$ record the final cooling stages upon exhumation to the upper crust $\left(\mathrm{ca} .300{ }^{\circ} \mathrm{C}\right)$ [1]. The studied rocks result from the metamorphism of continental margin sediments in the deep root of this Cryogenian-Ediacaran continent-continent collisional zone, which is related with the early phases of western Gondwana formation. The retrograde path records exhumation to $600{ }^{\circ} \mathrm{C}$ at $<1.0 \mathrm{GPa}$ at a relatively slow integrated cooling rate, of $c a .6{ }^{\circ} \mathrm{C} / \mathrm{Ma}$ (to the peak in $635 \mathrm{Ma}$ to retrograde in $590 \mathrm{Ma}$ ). This slow cooling rate can be partially explained by the increase of melt production during the decompression. The cooling rate of the final stage of the retrograde $P-T-\mathrm{t}$ path, based on the muscovite age, is faster (ca. $15{ }^{\circ} \mathrm{C} / \mathrm{Ma}$ ) than calculated for the earlier phase. We infer that channel flow occurred in the presence of melt during the metamorphic peak ( $c a .630 \mathrm{Ma}$ ), transitioning to localized fault slice tectonics during later stages of the $P-T-\mathrm{t}$ path, at ca. $590 \mathrm{Ma}$ at lower temperatures (e.g. [2]). This interpretation would be consistent with switching from a slow cooling rate during initial exhumation in a viscous channel to faster cooling in a fault-block dominated regime.

[1] Valeriano et al. (2000). Revista Brasileira de Geociências 30(1), 195-199. [2] Chakraborty et al. (2017) Lithos 282-283, 464-482 